\title{
The Obama Moment
}

T

he election of Barack Obama on November 4 to serve as the next president of the USA

was a triumph of hope over history for America. In these perilous times we, along with millions in other lands, have pinned our hopes for the future on the intellect, inspiration and compassion of this gifted leader. Obama raised expectations in his campaign - about what he expected from us as Americans, and about what we and the world could expect from an American administration he led. He could not have known, starting out, just how great the challenges would be.

This is widely recognized as a transformative moment in the history of the USA and, perhaps, the world. The neo-liberal model - which views greed as good and wealth as a reward for virtue, which believes that markets possess infinite wisdom and regulation and unions can only detract, and which discredits every objection to rising inequality and upward redistribution of income as an unwarranted assault on the class that creates prosperity - has, for all intents and purposes, imploded. It clearly is no longer viable. How else to explain Treasury Secretary Henry Paulson's nationalization in all but name of the insurance giant AIG? The admission by former Fed chair, Alan Greenspan, that he was wrong to believe financial markets would self-regulate? The calls for re-regulation of financial markets from the architects of deregulation in administrations from Reagan to Clinton and Bush not least of all from a chastened Robert Rubin and Lawrence Summers?

Of course the news of the demise of the neoliberal model may not yet have reached all of its defenders. The IMF and the World Bank still operate on the old principles. Some governments in Europe continue to run budget surpluses or attempt to meet the Maastricht requirements. This is a threat to the quick recovery of a globally integrated economy. But, as Nobel laureate Joseph Stiglitz observed, the neoliberal economic and political model is no more able to survive the fall of Wall Street than the economic and political model of the Soviet Union was able to survive the fall of the Berlin Wall.

The question now is whether Barack Obama will rise to the challenges confronting America and the world and govern as a transformational president. Will his economic policies avert a long and deep recession in the USA and help restore world growth? Will he create institutions for America in the 21 st century that can sustain a strong middle class? Will he provide leadership on issues of climate change, of negotiation and resolution of armed conflicts, of nuclear proliferation, and of global financial regulation?

Financial markets in the USA and around the world tanked when it appeared Obama would wait until his inauguration to unveil his economic policies. The stock market dropped by 12 percent in four days in mid-November. It rose by an almost identical 12 percent over the next two trading days after he announced his economic team and his intention to launch a fiscal stimulus of $\$ 700$ billion over two years to create jobs and get the economy moving. To appreciate the boldness of this proposal one needs only to remember that a few short weeks ago Republicans were calling for spending cuts to balance the federal budget while Democrats were timidly proposing spending $\$ 100$ billion on extending unemployment insurance, revenue sharing with hard hit states, energy conservation and infrastructure investment. Just days before Obama's announcement a letter was released, signed by more than 375 economists, calling for fiscal stimulus of $\$ 300$ to $\$ 400$ billion a year suited to the scale of the crisis. The "big bang" announcement was widely welcomed.

Obama and his economic team clearly understand the need for an immediate boost to the economy. What is worrying, however, is what his economic advisors will propose in the medium term. It is well-remembered in the USA that recovery from the depression of the 1930s, which started with the election of Franklin Delano Roosevelt in 1932, was halted by the recession of 1937 when FDR reversed direction and raised taxes in response 
to demands for fiscal responsibility and budget balance. It is not reassuring, therefore, that the president-elect's top economic advisors - Timothy Geithner at Treasury, Lawrence Summers as senior economics advisor and Peter Orszag as budget director - have all been protégés of Robert Rubin and his commitment to balanced budgets, so-called "free" trade, and financial deregulation. There are no outsiders among Obama's top advisors to question this team's belief, mistaken in my view, that balanced budgets and fiscal surplus were the root cause of job growth in the last half of the 1990s. Rather, the dot-com boom and the reckless spending and increase in household debt that it spawned offset the decline in government debt and the budget surplus in the 1990s - a scenario not likely to be soon repeated.

Equally troubling, Rubin and Summers were instrumental in supporting deregulation, tearing down walls between banks, brokerage houses and insurance companies, and allowing them to trade in such unregulated and little understood financial instruments as collateralized debt obligations, structured investment vehicles and credit default swaps. Asking this team to lead the effort to restore safety to financial markets and re-regulate financial institutions strikes some as calling in the arsonists to put out the fire.

Obama has sought to reassure the American public that he understands the depth and breadth of their economic problems, that the financial system will be rescued, that their children will be able to afford college, and that they will get the health care they need and be able to retire some day. He has surrounded himself with economists and corporate and financial leaders. Labor leaders, however, are notable by their absence. With ordinary workers bearing the brunt of an economic and financial crisis not of their making, this is a situation much to be regretted. The sharp rise in inequality in the USA over the past 30 years is due, in no small measure, to the weakening of American unions. Ronald Reagan's attack on the Air Traffic Controllers' union, like Margaret Thatcher's on the miners' union, helped set the stage for that decline. Any meaningful effort to reduce inequality - a goal shared by the president-elect and his team of economic advisors - depends on organized labor assuming a role as advocate for working people and countervailing force to the actions of corporate leaders.

But crisis management will not be sufficient. The new administration will need to create institutions that serve the American people in the 21st century as well as Social Security, unemployment insurance, the National Labor Relations Act and other New Deal initiatives served in the 20th and beyond. The USA faces grave challenges and time to address them is short. We need to work on climate change and our dependence on nonrenewable energy, on access to health care, on care for young children and for an aging population, on enabling workers to take time to care for their families and themselves, on educating children and preparing workers to be productive, and on assuring a dignified and financially secure old age. This is the change Obama promised, and that inspired so many.

Whether Obama will use America's still considerable power and his own prestige to repair the damage done to world peace, to human rights, and to restraints on nuclear proliferation remain to be seen. Foreign policy was the main point of contention between Obama and Hillary Clinton. Proposing her for Secretary of State signals Obama's intention to pursue a bipartisan foreign policy, but raises questions for those who chose Obama over Clinton.

Rahm Emanuel noted that a crisis provides the opening for bold initiatives and should never be wasted. How Obama uses this opening will determine how well the USA and global economies will function and the kind of world we will leave to our children.

Eileen Appelbaum

Economist and professor at Rutgers University (USA) and University of Manchester (UK), member of the advisory board of the Center for Economic Policy and Research in Washington, DC. 